\title{
Chemical composition, antimicrobial and antileishmanial activity of essential oil of Juniperus excelsa M.Bieb. from Ziarat, Balochistan
}

Hira Kakar ${ }^{1}$, Ashif Sajjad ${ }^{1 *}$, Sabeena Rizwan ${ }^{2}$, Khalid Mahmood ${ }^{1}$, Zahid Mehmood $^{1}$, Mohammad Azam ${ }^{1}$, Irfan Hafeez ${ }^{3}$, Atta Mohammad Sarangzai ${ }^{4}$, Akhtar Nadhman ${ }^{5}$ and Masoom Yasinzai ${ }^{5}$

1. Institute of Biochemistry, University of Balochistan, Sariab Road, Quetta-Pakistan

2. Department of Chemistry, Sardar Bahadur Khan Women University, Quetta-Pakistan

3. PCSIR Laboratories Complex, Lahore-Pakistan

4. Department of Botany, University of Balochistan, Sariab Road, Quetta-Pakistan

5. Centre for Interdisciplinary Research in Basic Sciences, International Islamic University, Islamabad-Pakistan *Corresponding author's email: ashifsajjad@hotmail.com; ashif.biochem@uob.edu.pk

Citation

Hira Kakar, Ashif Sajjad, Sabeena Rizwan, Khalid Mahmood, Zahid Mehmood, Mohammad Azam, Irfan Hafeez, Atta Mohammad Sarangzai, Akhtar Nadhman and Masoom Yasinzaia. Chemical composition, antimicrobial and antileishmanial activity of essential oil of Juniperus excelsa M.Bieb. from Ziarat, Balochistan. Pure and Applied Biology. Vol. 6, Issue 3, pp786-796. http://dx.doi.org/10.19045/bspab.2017.60083

Received: 15/03/2017

Revised: $15 / 06 / 2017$

Accepted: 16/06/2017

Online First: 22/06/2017

Abstract

Essential oils isolated from leaves, barriers and from their mixture of Juniper (Juniperus excelsa M.Bieb) growing in Ziarat district. Essential oils were obtained by Clevenger-type apparatus, and components identified by gas chromatography mass spectroscopy (GC-MS). A total 27 components were identified which were inconsistent in their composition in the essential oils of J.excelsa, where five major variable components were: limonene (15.5-28.59\%), followed by $\alpha$ pinene $(5.01-14.04 \%)$, cedrol $(4.68-14.5 \%)$, $\delta$-elemen $(6.9-13.01 \%)$ and $\delta$-cadinene $(5.2-$ $12.06 \%)$. Essential oils were evaluated for their in vitro antimicrobial activity against five bacterial species by disk diffusion method. J. excelsa essential oils showed antibacterial activity against tested organisms whilst the highest inhibition zone was observed for E. coli. Antileishmanial activity of essential oils isolated from juniper leaves, barriers and their mixture were also determined by using different concentration from $(0.01 \mathrm{ng} / \mathrm{ml}$ to $100 \mu \mathrm{g} / \mathrm{ml})$. The $\mathrm{IC}_{50}$ value of all three essential oils were $0.0065 \mu \mathrm{g} / \mathrm{ml}, 0.0088 \mu \mathrm{g} / \mathrm{ml}$ and $0.0093 \mu \mathrm{g} / \mathrm{ml}$ respectively and demonstrated almost 100 times more antileishmanial activity in comparison to the standard Amphotericin B.

Keywords: Juniperus excels; Antimicrobial activity; Antileishmanial activity; Essential oil composition

\section{Introduction}

Juniperus forests along with certain plants and animals forms an ecosystem found in the Balochistan province southwest of Pakistan, which is unique in its qualities due to existence in dry and unfavorable weather 
conditions. Juniperus forests are not only scarce genetic asset but also a strong heritage of the province as considered in the most ancient species of trees due to which they are often named as "Living Forest Fossil" [1]. The elevation where Juniperus forests are abundant ranges from 2000-3350 meters. Their geographic location extends between latitude 30 degrees $18 \mathrm{~N}-30$ degrees $30 \mathrm{~N}$ and longitude ranging from 67 degrees 54 E-67 degrees 67 E [2]. Koh I Khlifat $3475 \mathrm{~m}$ is the highest peak falling under Ziarat district. Physical composition of the area includes asymmetrical hard ridges, upright terrain in addition to small valleys usually commencing from the east and ending towards west. Dry temperate climate is usually experienced in Ziarat district [3]. Few herbariums have classified Juniperus into 54 different species that are scattered all over the world which includes South Asia, West Asia, Central Asia, North Africa, Europe and North America [4]. Six species out of above mentioned 54 species including $J$. excelsa exists in Pakistan, a major portion of which lies in the northern areas of Pakistan and Balochistan province. Open canopy is one of the attributes of juniper forests. Their regeneration is usually poor and their growth rate is considered to be slowest as compared to others. They are spread out in an area of 141,000 hectares. The large area covering 100,000 hectares are spotted in Ziarat district and Zarghun area adjacent to the provincial capital Quetta [5]. Herboi hills located in Kalat district also offer a fair sum of area of junipers. Juniper forests in addition to the mountains cover almost 35,325 hectares of area of the whole Ziarat district which constitutes $54 \%$ of the total area of the district [5]. Personnel working with the field of forestry find these forests of great significance to their study which includes the age, sex, size and growth rates of different species.
Male and ovulate strobili are born at ends of short twigs or along the twigs, mostly on different trees (dioecious) or in a few species on the same tree (monoecious). Male flowers are visible in January while female flowers appear in the mid of March. Depending upon climatic conditions, the male flowers become mature up to April. In the meantime the female flowers also become ready to receive the pollen, which are very rapidly shed by the male flowers. Abundant pollen is produced and can be seen as yellowish powder in the air. Female flowers are greenish in colour and are found at the tips of new branches like the male flowers. The formation of small greenish globose berries takes place soon after pollination and can be observed in the month of May, very minute in size, growing progressively and become fully mature in November-December next year [1, 6, 7]. The Juniperus species are characterized by large amount of essential oil in berries and needles as well as in wood and seed. In the last decade the composition of the berries essential oils of $J$. excelsa was investigated and some data were published recently. The berries essential oil of subsp. excelsa is characterized by presence of very high amounts of $\alpha$-pinene, followed by cedrol, Lverbenol and D-verbenol and/or as predominant components: 1,4-cineole and limonene, myrcene, limonene, caryophyllene, $\delta$-elemene and cedrol, or cedrol, myrcene and limonene [8]. In addition to genetic makeup the oil composition of Junipers has also been reported to change due to geographic variation, age of plant, season of harvesting, and interspecies differences. Juniper berry oil is known to be a pain reliever and has been reported to cure tuberculosis, jaundice, and eczema among so many other ailments [9].

Juniper oil is of utmost importance to the pharmacists as the oil is used in different 
medicines for treating different diseases relating to stomach, joints and muscles [10]. They are sometimes used as antiseptics as well. Juniper oil extracts its source from juniper berries botanically known as Baccae Juniperi. The same oil is also extracted from $J$. communis but the proportion is low as compared to the former [11, 13]. Majority portion up to $60 \%$ constitutes monoterpenes which are basically of utmost importance to the biologists.

Juniper is known for having insect repellent, disinfectant and antifungal properties, which made its use traditionally to use for the treatment of respiratory, gastrointestinal diseases, jaundice and tuberculosis $[14,15]$. It is reported that due to volatile chemical components $J$. excelsa contain considerable antibacterial activity [16, 17]. In Iran, Lebnon and Oman J. excelsa also used traditionally to treat asthma, blood pressure, common cold, bronchitis, tuberculosis and jaundice [15, 18-26]. Different juniper species are also reportedly used in traditional medicine as well as for the treatment of bronchitis, hyperglycemia, intestinal worms, liver disease, pneumonia, tuberculosis, ulcers and wound healing [17]. Leishmaniasis is amongst the major abandoned diseases. According to the World Health Organization data, which affects 350 million people worldwide and Pakistan is also among the endemic regions. Some studies have already conducted on antileishmanial activity of leaf, fruit and their organic solvents fraction of leaf of $J$. excelsa on L. major. Crude methanolic extract in addition to its portions chloroform fraction and di-ethyl ether fraction of $J$. excelsa berries were evaluated biologically and significant antileishmanial activity was depicted by chloroform fraction [20]. The antileishmanial activity of leaf and fruit and their organic solvents extracts were studied and the extracts of leaf showed significant activity on in vitro and in vivo model [27].
Leaves extract and its solvent fraction showed maximum antileishmanial activity as compared to fruits and its fraction of Greek juniper [28]. Essential oil of Juniperus species was also studied for its antileishmanial activity and the result was satisfactory [29].

The aims of the study were to identify compounds present in essential oils from leaves, berries and their mixture of Juniperus excelsa M.Bieb., to assess their antimicrobial activity and to evaluate their antileishmanial activity on Leishmania major.

\section{Materials and methods}

\section{Collection of plant materials}

Leaves and barriers from several trees of $J$. excelsa were collected from Ziarat, Balochistan and air dried at room temperature in the shade for few weeks.

\section{Extraction of essential oil}

Plants dried parts were crushed and each specimen (100g) leaves, Barriers and their mixture was subjected to hydro distillation for four hours in a Clevenger-type apparatus. The obtained oils were dried and stored separately at $4{ }^{0} \mathrm{C}$ for further analysis. The extraction of essential oil was carried out in triplicate.

Gas chromatography-mass spectrometry (GC-MS) analyses

GC-MS analyses were carried out with a Varian 3400 GC-MS framework outfitted with a DB-5 combined silica section $(30 \mathrm{~m}$ $\times 0.25 \mathrm{~mm}$, film thickness $0.25 \mathrm{~mm}, \mathrm{~J} \& \mathrm{~W}$ Scientific Corp.). The oven temperature was set at 50 to $260^{\circ} \mathrm{C}$ at a rate of $4^{\circ} \mathrm{C} / \mathrm{min}$. Exchange line temperature was $270^{\circ} \mathrm{C}$, Helium was utilized as the transporter gas with a straight speed of $31.5 \mathrm{~cm} / \mathrm{sec}$., split proportion was 1:60, vitality of ionization was $70 \mathrm{eV}$, check time was $1 \mathrm{sec}$., and mass extent was from 40 to $300 \mathrm{amu}$ (Resolution) recognizable proof of aggravates. Constituents were distinguished by examination of their mass spectra with those 
in a PC library (LIBR-TR and Wiley-5 lib.) or by means of real mixes. Distinguishing proof was affirmed by correlation of their maintenance files either with those of credible mixes or with information in the writing [30].

\section{Antimicrobial screening of the essential oils}

The antimicrobial activity of each extracted essential oil was assessed against five different bacterial species by disk diffusion method. The obtained microorganisms were from microbial culture collection unit of Microbiology Department, PCSIR, Lahore. The microorganisms used in this study were Staphylococcus aureus, Thiobacillus ferrooxidans (TBF), Leptospirillum ferrooxidans (LSF), Thiobacillus thiooxidans and Escherichia coli.

\section{Disc diffusion method}

Paper discs of $6 \mathrm{~mm}$ in diameter were impregnated with $30 \mu \mathrm{l}$ of essential oil dissolved in dimethyl sulphoxide (DMSO) at a final concentration of 5, 10, and 20\% v/w and transferred onto the Mueller-Hinton agar (Oxide UK) plates, the surface was spread with $0.5 \mathrm{ml}$ of bacterial suspension adjusted to $3 \times 10^{8} \mathrm{CFU} / \mathrm{ml}$ (1 MacFarland's standard). For negative control DMSO was used. Antibiotics Tetracycline (30 $\mu \mathrm{g} /$ disk) and Gentamicin (30 $\mu \mathrm{g} /$ disk) of commercial standard were used as positive controls. The diameter of inhibition zone was measured in millimeters $(\mathrm{mm})$ after incubation at $37 \pm 1^{\circ} \mathrm{C}$ for $24 \mathrm{hrs}$. Tests were carried out in triplicate. Sensitivity of the bacterial species to the essential oils was determined comparing the sizes of inhibitory zones [31].

\section{Antileishmanial activity}

The antileishmanial screening of the essential oil was performed in flat-bottomed plastic 96-well tissue plates. An amount 130 $\mu 1$ of 199 medium was added in wells of 96 well micro-titer plates (SPL Company). 70 $\mu l$ of $J$. excelsa essential oil was added in the first well and then serially diluted. $70 \mu \mathrm{l}$ was discarded from the last well to keep the final volume $130 \mu \mathrm{l}$. $100 \mu \mathrm{l}$ parasite culture was added in each well and 2 rows were left for positive and negative control. DMSO was taken as negative control and successively diluted in the 199 medium. Glucantime was taken as positive control and was also serially diluted in 199 medium. Micro-titer plates were kept in incubator (DNP-9022) at $24^{\circ} \mathrm{C}$ for 72 hours. Assay was performed in triplicate. After 72 hours, $20 \mu \mathrm{l}$ was picked from each dilution and placed on Neubauer counting chamber and live parasites were counted under microscope. $\mathrm{IC}_{50}$ values of $J$. excelsa essential oil having anti- promastigotes activity were calculated by Graph Pad Prism® software.

\section{Results and discussion}

The yield of the obtained essential oils by hydro distillation of leaves, berries and mixture of $J$. excelsa was $1.15,1.17$ and $1.14 \%$ respectively. The individual color of the essential oil was light yellowish transparent liquids with characteristic turpentine like odor. The GC/MS analysis of the juniper essential oil is detailed in Table 1 which showed that there were 27 compounds present in three essential oils. The components might be assigned to three diverse classes: monoterpene, diterpene, and sesquiterpene hydrocarbons which were present in all samples, while an alcoholic compound was also present. In J. excelsa essential oils of leaves, berries and mixture ten common constituents were identified, all analyzed samples were rich in limonene (15.5 - 28.59\%), followed by $\alpha$-Pinene $(5.01-14.04 \%)$, cedrol $(4.68-14.5 \%), \delta-$ elemen $(6.9-13.01 \%), \delta$-cadinene (5.2$12.06 \%)$, 6-epi- $\alpha$-cubebene $(2.85-8.31 \%)$, terpine-4-ol (4.71-5.91\%), bornyl acetate (2.79-3.7\%), cembrene A (1.29-1.58\%) and cembrene C (0.36-0.53\%). Two common constituents identified in leaves and berries 
essential oils were: $\beta$-pinene $(10.15 \%$, $8.46 \%$ ) and isoaromadendrene epoxide $(1.07 \%, 1.09 \%)$ respectively. Three common constituents identified in essential oils of berries and mixture were: cis- $\beta$-terpinyl acetate $(7.607 \%, 15.14 \%), \quad \gamma$-terpineol $(4.52 \%, 5.64 \%)$ and $\beta$-eudesmol $(1.83 \%$, $1.51 \%)$ respectively. In essential oils of leave \& mixture only one common component $\beta$-elemen (3.6\%) was identified. The dissimilarities between leaves, berries and mixture essential oils exist. In essential oil of leaves six components: 2-carene $(2.07 \%)$, perillene $(3.26 \%)$, caren-4-ol (2.81\%), cymene-8-ol (2.67\%), spathulenol $(1.4 \%)$ and 1-heptatriacotanol $(0.43 \%)$ were identified, which were absent in essential oils of berries and mixture. In essential oil of berries 13-epi manoyl oxide $(0.28 \%)$ was identified which was not present in essential oils of leaves and mixture. Three components cis-verbenol $(1.97 \%), \quad \gamma$ muurolene $(2.33 \%)$, $\alpha$-cadinol (1.09\%) were identified in essential oil of mixture and they were absent in essential oils of leaves and berries.

The composition of the essential oils of $J$. excelsa described in this study, numerous similarities and/or differences could be found. The overall composition of the essential oils is comparable to previously reported study by Khoury et al. [32].

Contents present in essential oil of $J$. excelsa leaves and by comparing with already published data the percentage of limonene in the present study is closed to a study that was conducted on J. excelsa growing wild in Greece which was (22.7\%) [33]. While, in three different studies it has been reported that the predominant components identified in leaves essential oil from $J$. excelsa from Greace, Turkey and Iran contained $\alpha$-pinene $(22.5 \%, 29.7 \%$ and $32.34 \%)$ and cedrol $(28.1 \%, 25.3 \%$ and $13.06 \%)$ respectively [34-36]. A study also reported that essential oil of $J$. excelsa leaves as a rich source of cedrol, a valuable component for perfumes [37]. Another study was conducted to find out if geographical variation can influence the presence of volatile components and a comparison was made among $J$. excelsa leaves essential oil samples from Bulgaria, Cyprus, Greece and Turkey, the component cedrol (11.3-35.8\%) was found predominant in all oils [38]. The components $\alpha$-pinene and cedrol and their percentage are higher as compare to the present study. A lot of other authors reported that in essential oil of $J$. excelsa berries $\alpha$-pinene as a main component ranged from 34-47.64\% [35, 36, $39-41]$ and up to $70.81 \%$ in the sample from south-east Macedonia [8]. The Serbian author reported that in berries essential oil of $J$. excelsa contained $\alpha$-pinene (5.2\%) [42], which is almost similar and terpinen-4-ol $(1.15 \%)$ was a bit low to that of present study. In Iranian samples it was found that the amount of $\alpha$-pinene, limonene and cedrol were $(22.5 \%, 28 \%$ and $22.7 \%)$ respectively [33], by comparing the obtained components and their amount presented in Table 1, dissimilarities with respect to components percentage and their abundance were observed. Major and minor components present in Omani $J$. excelsa berries are almost same as reported in this study while their percentages are not same [43].

The components present in essential oil of mixture (leaves and berries) of J. excelsa the amount of the components limonene, cedrol and $\alpha$-pinene followed a bit same pattern as that of essential oils of leaves and berries. Variation among the identified components in all three essential oils could be due to the interaction between different oil components that can be of four different kinds: antagonistic, synergistic, additive and/or indifferent. Antagonism means that the effects of one or both components are less when combined together than used separately. Synergism gives a better effect when two components are used together 
than used individually. Additive interaction means that the effect is same when the two components are put together than apart. While indifferent means that there is no interaction at all [44]. As mentioned above when two components interact with each other, for example in the essential oil limonene was in leaves $(15.5 \%)$, berries $(25.35 \%)$ and in mixture $(28.59 \%)$ respectively, according to the interaction between different essential oil components it is synergistic component because when leaves and barriers combined together for essential oil extraction the extracted mixture oil gives the better effect in term of percentage of a component as compare to essential oil of berries.

Table 1. Chemical composition (\%) of the essential oils of $j$. excelsa from Ziarat, Balochistan

\begin{tabular}{|l|c|c|c|c|c|c|}
\hline \multirow{2}{*}{ Compounds } & \multicolumn{2}{|c|}{ Leaves } & \multicolumn{2}{c|}{ Berries } & \multicolumn{2}{c|}{ Leaves+ Berries (Mixture) } \\
\cline { 2 - 7 } & Rt & \%age & Rt & \%age & Rt & \%age \\
\hline Limonene & 4.195 & 25.35 & 4.199 & 15.5 & 4.177 & 28.59 \\
\hline$\alpha$-Pinene & 5.614 & 14.04 & 5.61 & 5.01 & $5.58-$ & 10.01 \\
\hline$\beta$-Pinene & 6.358 & 10.15 & 6.521 & 8.46 & - & - \\
\hline 2-Carene & 7.193 & 2.07 & - & - & - & - \\
\hline Perillen & 7.388 & 3.26 & - & - & - & - \\
\hline Caren-4-ol & 8.337 & 2.81 & - & - & - & - \\
\hline Terpine-4-ol & 8.795 & 5.28 & 8.89 & 4.71 & 8.801 & 5.91 \\
\hline Cymene-8-ol & 9.35 & 2.67 & - & - & - & - \\
\hline Barnylacetate & 10.094 & 3.7 & 10.15 & 2.84 & 10.117 & 2.79 \\
\hline$\beta$-Elenen & 11.004 & 3.6 & - & & 11.05 & 3.13 \\
\hline$\delta$-Elenen & 11.679 & 6.9 & 11.994 & 13.01 & 11.77 & 9.04 \\
\hline$\delta$-Cadinene & 12.532 & 5.2 & 13.259 & 12.06 & 13.235 & 1.67 \\
\hline 6-epi- -Cubebene & 12.961 & 2.85 & 12.675 & 8.31 & 12.566 & 3.77 \\
\hline 10 -epi-Elemol & 13.602 & 2.52 & - & - & 13.642 & 1.58 \\
\hline Cedrol & 14.7 & 4.68 & 14.897 & 14.5 & 14.872 & 10.35 \\
\hline (-)-Spathulenol & 15.942 & 1.4 & - & - & - & - \\
\hline Iso aromadendrene epoxide & 16.686 & 1.07 & 15.84 & 1.09 & - & - \\
\hline Cembrene A & 17.452 & 1.46 & 17.501 & 1.58 & 17.47 & 1.29 \\
\hline 1-Heptatriacotanol & 18.7 & 0.43 & - & - & - & - \\
\hline Cembrene C & 19.833 & 0.53 & 19.86 & 0.36 & 19.844 & 0.36 \\
\hline Cis- $\beta$-Terpinyl acetate & - & - & 6.498 & 7.607 & 6.569 & 15.14 \\
\hline Cis-Verbenol & - & - & - & - & 8.423 & 1.97 \\
\hline$\beta$-Eudesmol & - & - & 16.736 & 1.83 & 16.646 & 1.51 \\
\hline$\gamma$-Terpineol & - & - & 7.203 & 4.52 & 7.25 & 5.64 \\
\hline$\gamma$-Muurolene & - & - & - & - & 12.297 & 2.33 \\
\hline Manoyl Oxide,epi-13 & - & - & 18.733 & 0.28 & - & - \\
\hline$\alpha$-Cadinol & - & - & - & - & 15.209 & 1.09 \\
\hline & & & & & & \\
\hline & $-R e n t$ & \\
\hline
\end{tabular}

Rt: Retention time (min), - not detected

The result of the antibacterial activity of the j.excelsa essential oil by the disc diffusion method is given in the Table 2. The microorganisms tested were Staphylococcus aureus, Thiobacillus ferrooxidans (TBF), Leptospirillum ferrooxidans

(LSF) 
Thiobacillus Thiooxidans and Escherichia coli. All bacterial species tested are sensitive to the essential oils of $J$. excelsa leaves, berries and mixture with the inhibition zones ranging from $11.9 \mathrm{~mm}$ to $22.7 \mathrm{~mm}, 12.7 \mathrm{~mm}$ to $23.4 \mathrm{~mm}$ and $12.8 \mathrm{~mm}$ to $24.1 \mathrm{~mm}$ respectively. The lower values were found for the tested Gram-positive bacteria as compared to the tested Gram-negative bacteria. Omani authors reported that the essential oil of $J$. excelasa berries does not contain any antimicrobial activity against Staphylococcus aureus and Escherichia coli which is contradictory to the present study [43]. In another study the authors reported that $J$. excelsa essential showed less antimicrobial activity against the tested microorganisms [45]. It has been reported that the essential oils are usually believed to be active when they show minimum inhibitory concentration (MICs) of 128 $\mathrm{mg} / \mathrm{ml}$ and/or below [46]. The essential oils isolated from leaves and twigs of $J$. excelsa growing wild in Lebanon showed antimicrobial activity against Staphylococcus aureus but Escherichia coli was resistant [32]. Therefore, the presented results of antimicrobial activity of $J$. excelsa essential oils similarities and dissimilarities are found in literature that could probably be due to the diverse percentage of chemical constituents present in essential oils.

Table 2. Antimicrobial activity of J. excelsa essential oils determined by diffusion method

\begin{tabular}{|l|c|c|c|}
\hline \multicolumn{3}{|c|}{ Inhibition zones (mm \pm SE) } \\
\hline Bacterial species & Leaves & Berries & Leaves + Berries (Mixture) \\
\hline Staphylococcus aureus & $11.9 \pm 04$ & $12.7 \pm 0.7$ & $12.8 \pm 0.5$ \\
\hline Thiobacillus ferrooxidans (TBF) & $19.8 \pm 0.7$ & $23.3 \pm 12$ & $24.1 \pm 0.5$ \\
\hline Leptospirillum ferrooxidans (LSF) & $17.0 \pm 0.9$ & $14.9 \pm 0.7$ & $15.9 \pm 0.7$ \\
\hline Thiobacillus Thiooxidans & $16.8 \pm 0.5$ & $17.2 \pm 0.6$ & $17.3 \pm 0.8$ \\
\hline Escherichia coli & $22.7 \pm 0.5$ & $23.4 \pm 0.7$ & $23.2 \pm 0.7$ \\
\hline
\end{tabular}

mm (millimeter), SE (Standard Error)

Table 3 displays $\mathrm{IC}_{50}$ values of $J$. excelsa essential oil studied for antileishmanial activity. The essential oil of leaves, berries and mixture were checked for their activity and possible mode of action against Leishmania major parasites at different concentrations, i.e., from $(0.01 \mathrm{ng} / \mathrm{ml}$ to 100 $\mu \mathrm{g} / \mathrm{ml})$. The $\mathrm{IC}_{50}$ of $J$. excelasa leaves essential oil was in the range of $0.0065 \mu \mathrm{g} / \mathrm{ml}$, while the $\mathrm{IC}_{50}$ value of berries was $0.0088 \mu \mathrm{g} / \mathrm{ml}$ and the $\mathrm{IC}_{50}$ value of mixture was in the range of $0.0093 \mu \mathrm{g} / \mathrm{ml}$. The $J$. excelasa mixture essential oil was 10 times more active than the oil extracted from barriers and leaves (Table3). Further, all the three essential oils (leaves, berries and mixture) were found more active than the standard drug Amphotericin B $(0.34 \mu \mathrm{g} / \mathrm{ml})$.
A Juniperus species (J. oxycedrus) berries and leaves essential oil showed $\mathrm{IC}_{50}$ values of 51 and $127 \mu \mathrm{g} / \mathrm{mL}$ respectively [29], the concentrations were much higher to inhibit Leishmania growth than $J$. exculsa leaves, berries and mixture essential oils reported in present study. Antileishmanial activities of Greek J. excelsa leaf and fruit solvent extracts and their related fractions showed strong inhibitory effects against Leishmania major promastigotes [28]. The obtained result of antileishmanial activity presented in this study is comparable to the previously reported (PEGylated silver doped zinc oxide nanoparticles as novel Photosensitizers for photodynamic therapy against Leishmania [47]. 
Table 3. In vitro activity of essential oils of J. excelsa against Leishmania major (promastigote)

\begin{tabular}{|l|c|}
\hline Sample & $\mathrm{IC}_{50}(\boldsymbol{\mu g} / \mathbf{m l})$ \\
\hline Leaves & 0.0065 \\
\hline Berries & 0.0088 \\
\hline Leaves + Berries (Mixture) & 0.0093 \\
\hline Amphotericin B* & 0.34 \\
\hline
\end{tabular}

*Reference drug. $\mathrm{IC}_{50}$ values express the concentration of the sample to inhibit cell growth or degradation by $50 \%$

\section{Conclusions}

Twenty-seven compounds were identified in $J$. excelasa essential oils from the leaves, berries and mixture. Most abundant components in three oils were: limonene, $\alpha-$ pinene, cedro, $\delta$-elemen, $\delta$-cadinene, 6-pi- $\alpha$ cubebene and terpine-4-ol. All three obtained oils showed antimicrobial activity against five bacterial strains with the inhibition zones from $11.9 \mathrm{~mm}$ to $24.1 \mathrm{~mm}$. The results revealed that antimicrobial activity of mixture was higher than those of the leaves and berries. Antileishmanial activity of J. excelsa essential oils at low concentrations as shown in the present study seems more advantageous if compared to other essential oils and/or photosensitizers tested against Leishmania major parasites. The $\mathrm{IC}_{50}$ values described here showed that $J$. excelsa essential oils possess an interesting antileishmanial activity.

Further studies will be performed as all three essential oils from $J$. excelasa demonstrate antimicrobial and antileishmanial activities. Obtained essential oils contain a strong and lasting aroma which could possibly be used for a number of applications such as in cosmetics, agrochemicals, foods and medicines.

\section{Authors' contributions}

Conceived and designed the experiments: $\mathrm{H}$ Kakar, A Sajjad, S Rizwan \& K Mahmood, Performed the Experiments: H Kakar, I Hafeez \& A Nadhman, Analyzed the Data: A Sajjad, K Mahmood \& A Nadhman, Contributed reagents/ materials/ analysis tools: Z Mahmood, M Azam, A M
Sarangzai \& M Yasinzai, Wrote the paper: H Kakar \& A Sajjad.

Acknowledgements

Special thanks to Balochistan Education Endowment Fund (BEEF), Government of Balochistan. We extend many thanks to the technical staff of PCSIR Laboratories Complex, Lahore, Balochistan Agricultural Research and Development Center (BARDC), Quetta and Department of Biotechnology, Quaid-i-Azam University, Islamabad, Pakistan for providing lab facilities. Thanks are also due to all those who helped us in the sample collection and preparation of this manuscript.

\section{References}

1. Sheikh MI (1985). Afforestation in juniper forest of Balochistan. Pakistan for Inst Peshawar $46 \mathrm{p}$.

2. Sarangzai MA, Ahmed M, Ahmed A, Tareen L \& Jan US (2012). The ecology and dynamics of Juniperus excelsa Forest in Balochistan-Pakistan. Pak J Bot 44(5): 1617-1625.

3. Champion GH, Seth SK \& Khattak GM (1965). Forest types of Pakistan. Pakistan Forest Institute, Peshawar pp. 238.

4. Anonymous (1994). IUCN Pakistan Programme. Conservation of Juniper Forests through community participation (PAK/98/G41) GEF Project Working plan for Brief pp. 1-55.

5. Khattak GM (1963). Juniper forests of Quetta civil division. Govt. Printing Press, West Pakistan. 
6. Quraishi MA \& Mohammad T (1971). Disease of Juniperus polycarpos C. Koch. Pakistan J For 391-394.

7. Zakaullah \& Badshah K (1977). Survey of Juniper dwarf mistletoe in Sasnamana State Forest of Balochistan. Pakistan J For 27(3): 143-146.

8. Sela F, Karapandzova M, Stefkov G, Cvetkovikj I \& Kulevanova S (2015). Chemical composition and antimicrobial activity of essential oils of Juniperus excelsa Bieb. (Cupressaceae) grown in $\mathrm{R}$. Macedonia. Pharmacognosy Res 7(1): 74-80.

9. Khajjak HM, Saeed M, Sattar F \& Ahmed FC (2011). Comparative analysis of essential oil contents of juniperus excelsa M. Beib. From Balochistan. FUUAST j Biol 1(1): 69-73.

10. Filipowicz N, Kaminski M, Kurlenda J, Asztemborska M \& Ochocka RJ (2003). Antibacterial and Antifungal Activity of Juniper Berry Oil and its Selected Components. Phytother Res 17: 227231.

11. Vernin G, Boniface C, Metzger J, Ghiglione C, Hammoud A, Suon K, Fraisse D \& Párkányi C (1988). GC-MSSpectra bank analysis of Juniperus communis needles and Berries. Phytochemistry 24: 1061-1064.

12. Sybilska D, Asztemborska M, Kowalczyk J, Ochocka RJ, Ossicini L \& Perez G (1994). Enantiomeric composition of terpenic hydrocarbons in essential oils from Juniperus communis L. J Chrom A 659: 389-394.

13. Ochocka JR, Asztemborska M, Zook DR, Sybilska D, Perez G \& Ossinini L (1997). Enantiomers of monoterpenic hydrocarbons in essential oils from Juniperus communis. Phytochemistry 44: 869-873.

14. Arnold-Apostolides N (1991). Ethnobotanique et Ethnopharmacologie de la Flore de Chypre et de l'Est
Mediterraneen', Publications $d u$ Centre Régional de Phytosociologie, Bailleul6 (2201): $105 \mathrm{p}$.

15. Khan M, Khan AU, Najeeb-ur-Rehman \& Gilani AH (2012). Pharmacological explanation for the medicinal use of Juniperus excelsa in hyperactive gastrointestinal and respiratory disorders. J Nat Med 66 (2): 292-301.

16. Pirani A, Moazzeni H, Mirinejad S, Naghibi F \& Mosaddegh M (2011). Ethnobotany of Juniperus excelsa M. Bieb (Cupressaceae) in Iran. Ethnobotany Research \& Applications 9: 335-341.

17. Khan M, Khan AU, Rehman NU, Zafar MA, Hazrat A \& Gilani AH (2012). Cardiovascular effects of Juniperus excelasa, are mediated through multiple pathways. Clin Exp Hypertens 34: 209216.

18. El Beyrouthy M, Arnold N, DelelisDusollier A \& Dupont F (2008). Plants used as remedies antirheumatic and antineuralgic in the traditional medicine of Lebanon. J Ethnopharmacol 120 (3): 315-34.

19. Almaarri K, Alamir L, Junaid Y \& Xie DY (2010). Volatile compounds from leaf extracts of Juniperus excelsa growing in Syria. Gas Chromatogr Mass Spectrom 10: 673-677.

20. Nabi S, Ahmed N, Khan MJ, Bazai Z, Yasinzai M \& Kaharaman YAL (2012). In vitro antileshmanial, antitumor activities and phytochemical studies of methanolic extract and its fractions of Juniperus excelsa berries. World Appl Sci J 19: 1495-1500.

21. Muhanmmad IM \& EL-Feraly FS (1992). Antibacterial diterpenes from the leaves and seeds of Juniperus excelsa M. Bieb. Phytotheraphy 6: 261-264.

22. Tumen I, Süntar I, Keles H \& Akkol EK (2012). A therapeutic approach for wound healing by using essential oils of 
Cupressus and Juniperus species growing in Turkey. Evid Based Complement Altern Med 1-7.

23. Mossa JS, Muhammad I, El-Feraly FS \& Hufforda CD (1992). 3,12Dihydroxyabieta-8,11,13-triene-1-one and other constituents from Juniperus excelsa leaves. Int J Plant Biochem 31: 2789-2792.

24. Fisher M \& Gardner AS (1995). The status and ecology of a Juniperus excelsa subsp. polycarpos, woodland in the northern mountainsof Oman. Vegetatio 119: 33-51.

25. Lesjak MM, Beara IN, Or ${ }^{` c i}{ }^{\prime} c$ DZ, Ana ckov GT, Balog KJ \& MimicaDuki'c NM (2011). Juniperus sibirica Burgsdorf. as a novel source of antioxidant and anti-inflammatory agents. Food Chem 24: 850-856.

26. El Mahi SA (2003). Juniper islands and plant diversity, a case study with remote and GIS in Karaj. Iran, International Institute for Geo-Information Sciences and Earth Observation, Enscheda $22 \mathrm{p}$.

27. Somayeh M (2014). Antileishmanial activity of leaf, fruit and fractions of leaf of Juniperus excelsa on L. major by in vitro and in vivo model. M.Sc. thesis. Shiraz University of Medical Sciences (Iran).

28. Mahmoodreza M, Gholamreza H, Razieh T \& Mohammad MZ (2016). Antileishmanial Activities of Greek Juniper (Juniperus excelsa M.Bieb.) Against Leishmania major Promastigotes. Journal of EvidenceBased Complementary \& Alternative Medicine 1-6.

29. Machado M, Santoro G, Sousa MC, Salgueiro L \& Cavaleiro C (2010). Activity of essential oils on the growth of Leishmania infantum promastigotes. Flavour Fragrance J 25: 156-160.

30. Adams RP (2017). Identification of essential oil components by gas chromatography mass spectroscopy, $5^{\text {th }}$ Ed. (online) Texensis Publishing Gruver, TX USA.

31. Murray PR, Baron EJ, Pfaller MA, Tenover FC \& Yolke RH (1995). Manual of Clinical Microbiology. Vol 6. ASM, Washington, DC.

32. Khoury M, El-Beyrouthy M, Ouaini N, Iriti M, Eparvier V \& Stien D (2014). Chemical Composition and Antimicrobial Activity of the Essential Oil of Juniperus excelsa M.Bieb. Growing Wild in Lebanon. Chem Biodivers 11(5): 825-30.

33. Salehi SP \& Mirza M (2006). Seasonal variation of the leaf and cone oil of Juniperus excelsa M. Bieb. J Med Plants 5: 50-8.

34. Adams RP (1990). The chemical composition of leaf oils of Juniperus excelsa M. Bieb. J Essent Oil Res 2: 458.

35. Topçu G, Gören AC, Bilsel G, Bilsel M, Çakmak O, Schilling J \& Kingston DGI (2005). Cytotoxic activity and essential oil composition of leaves and berries of Juniperus excelsa. Pharm Biol 43: 1258.

36. Emami SA, Abedindo BF \& Hassanzadeh-Khayyat M (2011). Antioxidant activity of the essential oils of different parts of Juniperus excelsa M. Bieb. subsp. excelsa and $J$ excelsa $\mathrm{M}$ Bieb subsp polycarpos (K Koch) Takhtajan (Cupressaceae) Iran J Pharm Res 10: 799-810.

37. Thappa RK, Aggarwal SG, Kapahi BK \& Sarin JK (1987). Juniperus excelsa leaf oil, a new source of cedrol. $J$ Nat Prod 50: 323-4.

38. Adams RP, Tashev AN, Baser KH \& Christou AK (2013). Geographic variation in volatile leaf oils of Juniperus excelsa M. Bieb. Phytologia 95: 279-85. 
39. Ehsani E, Akbari K, Teimouri M \& Khadem A (2012). Chemical composition and antibacterial activity of two Juniperus species essential oils. Afr J Microbiol Res 6: 6704-10.

40. Atas AD, Goze I, Alim A, Cetinus SA, Durmus N, Vural N \& Cakmak O (2012). Chemical composition, antioxidant, antimicrobial and antispasmodic activities of the essential oil of Juniperus excelsa subsp. excelsa. J Essent Oil-Bearing Plants 15: 476-83.

41. Asili J, Emami SA, Rahimizadeh M, Fazly-Bazzaz BS \& Hassanzadeh MK (2008). Chemical and antimicrobial studies of Juniperus excelsa subsp. excelsa and Juniperus excelsa subsp. polycarpos essential oils. J Essent OilBearing Plants 11: 292-302.

42. Sokovic M, Ristic M \& Grubisic A (2004). Chemical composition and antifungal activity of the essential oil of Juniperus excelsa berries. Pharm Biol 42: 328-34.

43. Weli AM, Al-Hinai SRK, Hossain MM \& Al-Sabahi JN (2014). Composition of essential oil of Omani Juniperus excelsa fruit and antimicrobial activity against food borne pathogenic bacteria. Journal of Taibah University for Science 8(3): 225-230.

44. Bassolé IH \& Juliani HR (2012). Essential Oils in Combination and Their Antimicrobial Properties. Molecules 17: 3989-4006.

45. Unlu M, Varder-Unlu G, Vural N, Donmez E \& Cakmak O (2008). Composition and antimicrobial activity of Juniperus excelsa essential oil. Chem Nat Compd 44: 129-131.

46. Cos P1, Vlietinck AJ, Berghe DV \& Maes L (2006). Anti-infective potential of natural products: how to develop a stronger in vitro 'proof-of-concept'. $J$ Ethnopharmacol 106(3): 290-302.

47. Nadhman A, Nazir S, Khan MI, Arooj S, Bakhtiar M, Shahnaz G \& Yasinzai M (2014). PEGylated silver doped zinc oxide nanoparticles as novel photosensitizers for photodynamic therapy against Leishmania. Free Radic Biol Med 77: 230-8. 